\title{
Management and Legal Aspects of the Symbiosis of Banking Institutions and Fintech Companies in the Credit Services Market in the Context of Digitization
}

\author{
VIKTORIIA VOVK ${ }^{1}$, ALINA DENYSOVA ${ }^{2}$, KATERYNA RUDOI ${ }^{3}$, TETIANA KYRYCHENKO ${ }^{4}$ \\ ${ }^{1}$ Department of International Management, KYIV NATIONAL UNIVERSITY OF TRADE AND ECONOMICS, \\ UKRAINE, E-mail: victoriavovk@ukr.net, ORCID: http://orcid.org/0000-0002-4816-4579 \\ ${ }^{2}$ Department of Administrative Law and Administrative Procedure, ODESA STATE UNIVERSITY OF INTERNAL \\ AFFAIRS, UKRAINE, E-mail: alinadenysova99@gmail.com, ORCID: http://orcid.org/0000-0002-4816-4579 \\ ${ }^{3}$ Department of Administrative Law and Procedure, ODESA STATE UNIVERSITY OF INTERNAL AFFAIRS, UKRAINE, \\ E-mail: alinaodu@gmail.com, ORCID: http://orcid.org/0000-0002-4816-4579 \\ ${ }^{4}$ Department of Civil Law and Procedure, KHARKIV NATIONAL UNIVERSITY OF INTERNAL AFFAIRS, UKRAINE, \\ E-mail: ynatavesher@gmail.com, ORCID: http://orcid.org/0000-0002-4816-4579
}

\begin{abstract}
The article examines the features of banks' lending activities and substantiates the prerequisites for strengthening their cooperation with financial companies, systematizes internal and external innovations used in the process of digitalization of the banking business. The periodization of the banking system from 2005 to the present in accordance with the strategic development goals and stages of the bank's life cycle has allowed to justify the relevant digitalization policy, appropriate for each period. It has been proved that the symbiosis of banks and fintech companies helps to increase the competitiveness and profitability of business in the long run. The importance of introduction of banking innovations in the crediting market as the most profitable direction of banking activity has been substantiated, the forecast of change in net interest income of Ukrainian banks for the post-pandemic period has been made. Based on the fact that the indicator of the country's success in implementing the norms and measures of the Digital Agenda for the EU and Digital Single Market is the Digital Economy and Society Index (DESI), which is determined for each EU country annually, the paper makes forecast changes in its components: Connectivity, Human Capital, Use of Internet, Integration of Digital Technology, Digital Public Services. The main factors that inhibit the processes of strengthening the interaction between banks and FinTech companies in Ukraine have been identified. The expediency of improving the current legislation of Ukraine taking into account the best European practices in the field of cooperation between banks and FinTech companies has been substantiated.
\end{abstract}

Keywords: Bank; FinTech companies; Legislation; Legal regulation; Competition; Credit services market; Digitization; FinTech-innovations; Financial and economic crisis; Coronavirus COVID-19 pandemic.

JEL classification: G01, G17, G21, G28

Received: April 09, 2021

Accepted: June 16, 2021 


\title{
Aspectos Jurídicos y de Gestión de la Simbiosis de las Entidades Bancarias y las Empresas Fintech en el Mercado de los Servicios de Crédito en el Contexto de la Digitalización
}

\author{
VIKTORIIA VOVK ${ }^{1}$, ALINA DENYSOVA ${ }^{2}$, KATERYNA RUDOI ${ }^{3}$, TETIANA KYRYCHENKO ${ }^{4}$ \\ ${ }^{1}$ Department of International Management, KYIV NATIONAL UNIVERSITY OF TRADE AND ECONOMICS, \\ UKRAINE, E-mail: victoriavovk@ukr.net, ORCID: http://orcid.org/0000-0002-4816-4579 \\ ${ }^{2}$ Department of Administrative Law and Administrative Procedure, ODESA STATE UNIVERSITY OF INTERNAL \\ AFFAIRS, UKRAINE, E-mail: alinadenysova99@gmail.com, ORCID: http://orcid.org/0000-0002-4816-4579 \\ ${ }^{3}$ Department of Administrative Law and Procedure, ODESA STATE UNIVERSITY OF INTERNAL AFFAIRS, UKRAINE, \\ E-mail: alinaodu@gmail.com, ORCID: http://orcid.org/0000-0002-4816-4579 \\ ${ }^{4}$ Department of Civil Law and Procedure, KHARKIV NATIONAL UNIVERSITY OF INTERNAL AFFAIRS, UKRAINE, \\ E-mail: ynatavesher@gmail.com, ORCID: http://orcid.org/0000-0002-4816-4579
}

\begin{abstract}
RESUMEN
El artículo examina las características de las actividades crediticias de los bancos y fundamenta los requisitos para fortalecer su cooperación con las empresas financieras, sistematiza las innovaciones internas y externas utilizadas en el proceso de digitalización del negocio bancario. La periodización del sistema bancario desde 2005 hasta la actualidad de acuerdo con los objetivos estratégicos de desarrollo y las etapas del ciclo de vida del banco ha permitido justificar la política de digitalización pertinente, adecuada para cada período. Se ha demostrado que la simbiosis de los bancos y las empresas fintech ayuda a aumentar la competitividad y la rentabilidad del negocio a largo plazo. Se ha corroborado la importancia de la introducción de innovaciones bancarias en el mercado crediticio como la dirección más rentable de la actividad bancaria, se ha realizado la previsión de la variación de los ingresos netos por intereses de los bancos ucranianos para el período post-pandémico. Basándose en el hecho de que el indicador del éxito del país en la aplicación de las normas y medidas de la Agenda Digital para la UE y el Mercado Único Digital es el Índice de Economía y Sociedad Digital (DESI), que se determina para cada país de la UE anualmente, el documento hace previsiones de cambios en sus componentes: Conectividad, Capital Humano, Uso de Internet, Integración de la Tecnología Digital, Servicios Públicos Digitales. Se han identificado los principales factores que inhiben los procesos de fortalecimiento de la interacción entre los bancos y las empresas FinTech en Ucrania. Se ha corroborado la conveniencia de mejorar la legislación actual de Ucrania teniendo en cuenta las mejores prácticas europeas en el ámbito de la cooperación entre bancos y empresas FinTech.
\end{abstract}

Palabras claves: Banco; Empresas FinTech; Legislación; Regulación legal; Competencia; Mercado de servicios de crédito; Digitalización; Innovaciones FinTech; Crisis financiera y económica; Pandemia de coronavirus COVID-19.

Clasificación JEL: G01, G17, G21, G28

Recibido: 09 de abril de 2021

Aceptado: 16 de junio de 2021 


\section{Introduction}

The COVID-19 pandemic has become one of the most urgent challenges for both the world economy and Ukraine's economy. Currently, the losses of world GDP caused by the pandemic already exceed the losses associated with the global financial and economic crisis of 2008, and may, according to various estimates, exceed USD 9 trillion. The pandemic has already affected all spheres of public life and may have become a catalyst for change in the directions for development of the world community. Experience shows, not only public authorities in the world, but also large and small businesses should move away from traditional models of activity and focus on the introduction of innovations that would ensure work in quarantine measures. In particular, this applies to business models of financial institutions. There has long been talk of the need for a symbiosis of banks and Fintech companies in order to form the latest competitive advantages and increase competitiveness in the banking market. This was due to the expansion of business boundaries in the globalization of world commodity markets and a change in the vector of shifting the emphasis of consumer preferences to accelerate access to financial resources, increase mobility, convenience and accessibility of settlement operations and reduce their cost. As a result of the pandemics, this issue has become more acute, as the majority of the bank's customers prefer remote forms of service and receiving banking services. Under such conditions, banks that will not be able to quickly adapt to the latest conditions of the banking business, will be forced to leave the market due to reduced customer base and deteriorating solvency.

The purpose of this work is to substantiate theoretical and methodological provisions, develop practical recommendations for creating conditions for deepening cooperation between banks and Fintech companies as a prerequisite for improving the efficiency of banking in the consumer lending market, as well as to determine the content and priorities of the state regulatory policy in digital transformation and digital development of the society, taking into account foreign experience.

Many scientific works are currently devoted to the study of the peculiarities of digitalization processes. Authors have investigated the features of informatization as a determining factor of globalization (Kuznetsov et al., 2020). Researchers have developed theoretical and applied aspects of information and communication technologies in the global economy, analyzed the impact of their processes on production, processing and transfer of information in all spheres of public life (Hrabovskyi et al., 2020).

Some works have been concentrated on the study of the impact of digitalization processes on the economy of Ukraine (Pantielieieva et al., 2018, Shkarlet et al., 2020).

Bilovodska, O., Starostina, A., Vovk, V., Moroz, O., Moroz, M. have investigated the essence of innovation as a factor of creating a new or improved product or technological process, and the features of innovation in the modern world (Bilovodska et al., 2020). Some issues of the use of implementation of marketing and legal tools in the process of commercialization for innovative products have also been covered in several works (Bilovodska et al., 2020, Bilovodska et al., 2014,).

Bilovodska, O., Kholostenko, A.; Mandrychenko, Z..; Volokitenko, O. have studied the influence of innovation management on business strategies of business entities (Bilovodska et al., 2021).

The development of the banking services market in the context of digitalization and the peculiarities of the use of innovative technologies in the implementation of certain types of banking activities have been covered in the work by Victoria Vovk and Associates (Vovk et al., 2020).

Shkarlet, S., Dubyna, M., Vovk, V., Noga, M. have conducted a comparative assessment of the financial markets of the EU and Ukraine based on the use of compositional model, highlighted differences, and identified prospects for the development of the banking sector of Ukraine (Shkarlet et al., 2019).

Directions for improving the financial management of the bank in modern conditions have been developed by Chmutova I., Vovk V., Bezrodna O. (Chmutova et al., 2017).

Vovk, V., Zhezherun, Y., Gudz, L., Perederii, O. have studied issues of banking business development in the conditions of intensification of digitalization processes and features of the introduction of 
innovative technologies in banking to increase competitiveness of banks (Vovk et al., 2021).

Dubyna, M., Zhavoronok, A., Kudlaieva, N., Lopashchuk, I. have determined the impact of modern digitalization processes on changing household credit behavior (Dubyna et al., 2021).

\section{Properties of the aggregation method}

The paper applies a linear trend line, which is used for data whose value has a proportional increase over the study period. To determine the linear trend line, the following formula is used: $y=m x+b$, where $\mathrm{m}$ is the angle of inclination, $\mathrm{b}$ is the coordinates of the point of intersection of $\mathrm{X}$-axis.

The prognostic model has been built on the principle of exponential smoothing; time lag 4 (4 quarters of the year); a multiplicative trend line taking into account the corresponding influence of the values of net interest income of banks of previous periods on the actual values of this indicator in the present and in the future, has been added (Malyarets et al., 2019).

To increase the objectivity of research methods and the results obtained on their basis, indicators according to the formula of exponentially weighted moving average (EMA) have been invented:

$$
E M A_{t}=a \cdot p_{t}+(1-a) \cdot E M A_{t-1}
$$

Where $E M A_{t}$ - is the value of the exponential moving average at the point $t$ (the last value in the case of a time series);

$E M A_{t-1}$ - is the value of the exponential moving average at the point $\mathrm{t}-1$ (the previous value in the case of a time series);

$p_{t}$ - is the value of the original function at time $t$ (the last value in the case of a time series);

$a$-is a smoothing constant, the coefficient characterizing the speed of decreasing weights, takes a value from 0 to 1 , the lower its value, the greater the influence of the previous values on the current value of the average.

The first value of the exponential moving average is usually taken equal to the first value of the original function:

$$
E M A_{0}=p_{0}
$$

The coefficient $a$ can be chosen arbitrarily, in the range from 0 to 1 .

For example, it can be expressed in terms of the averaging window size:

$$
a=\frac{2}{n+1}
$$

The trend indicators were allowed to see the current trend of banking activity, which is mainly based on the market of banking services.

\section{Legislation of FinTech}

In the EU, the creation of a single market (standards) of payments and The Single Euro Payments Area (SEPA) with the adoption of Directive 2007/64/EC on payment services in the internal market (PSD) in 2007, became the push to develop FinTech companies. Directive (EU) 2015/2366 on payment services in the internal market (PSD2) has helped to expand the ecosystem and increase the transparency of financial services (Podgorna et al., 2020). Since 2019, Ukrainian legislation has been harmonized with EU legislation (requirements of the Association Agreement with the EU), and the EU PSD2 Directive has been gradually implemented.

However, there is yet no single legal act that would regulate the field of FinTech in Ukraine, some areas are regulated by various laws. The sphere of payments is regulated by the laws of Ukraine "On payment systems and funds transfer in Ukraine", "On financial services and state regulation of financial services markets", "On electronic trust services", "On currency and currency transactions" and NBU 
regulations. The Law of Ukraine "On Consumer Lending" defines the general organizational and legal aspects of consumer lending in Ukraine for both banks and other credit institutions, in accordance with international legal standards. However, the issue of interaction between banks and FinTech companies in the consumer lending market is currently not regulated by the existing legislation (yaseen et al 2018).

A number of initiatives is aimed at digitalization in the Strategy for the Development of the Financial Sector of Ukraine until 2025, namely: Strategic Direction 5 "Innovative Development" - ensuring the development of FinTech market, digital technologies and regulatory platforms (ensuring the development of digital technologies, computer design, analysis of big data, blockchain, automation, robotization and the use of artificial intelligence (Babenko et al., 2019); studying the possibility of issuing e-hryvnia - digital currency of the central bank; strengthening cybersecurity).

In the context of digitalization of the economy, the issues of cooperation between banks and fintech companies in the consumer lending market need additional legal regulation (Naveed et al 2019).

\section{Results and discussion}

The specificity of the banking system is determined by the significant number of risks that accompany all banking operations. Conceptually, the place and role of a modern bank is determined by the following processes: in the market of banking services - the formation of conditions and opportunities to attract temporarily free funds of individuals and legal entities and their effective placement to meet the needs of the real sector and consumer needs; in a competitive environment distinguishing among competitors due to the implementation of existing competitive advantages and ensuring a dominant competitive position in the banking market or in its individual segments in the context of destabilizing impact of environmental factors. The current state of development of the banking sector, which is characterized by falling profitability in most business areas of banking and increasing competition in the consumer lending market against the background of the financial and economic crisis, requires a combination of these processes based on the transformation of banking business with a focus on the use of IT.

Factors that determine the need of business for additional financing include: the need to update production assets, seasonality of production, the need to cover the gaps between the duration of the production process and the period of product sales, fluctuations in individual consumer demand meeting the consumer needs of the population (purchase of consumer durables), cars, mortgages.

Stagnation of the credit market due to the negative impact of the global financial and economic crisis led to falling demand for bank credit products starting from 2008. During the pandemic period, this trend has only intensified and has led to a significant reduction in one of the most profitable banking business areas and increased competition in banking services, both by banks and by nonbanking organizations and FinTechs. All this ultimately necessitates a change in the traditional model of banking business and the improvement of credit products through the introduction of banking innovations in order to facilitate access of businesses and individuals to bank lending. During 20042008, the most attractive and at the same time the riskier area of banking resources was consumer lending, which is explained by the increase in effective demand from individuals. However, in the pandemic, the situation is diametrically opposed - the job cuts, the falling demand for certain goods and services to a minimum did not increase demand for credit products from customers, which caused the reduction of banks' loan portfolio. In addition, customers are increasingly preferring remote channels for banking services in general and credit services in particular (Internet banking, mobile banking, etc.). Under such conditions, an increasing share of the credit services market is occupied by banks that have introduced FinTech innovations (JSC CB PrivatBank, Monobank). The advantage of FinTech companies, which stimulate the penetration of innovations in the financial sector in the banking market, is that they combine innovative business models with technologies, reduce the cost of credit product for the client and expand the range of related services (insurance, online contracts, etc.). In 2015, the average level of FinTech penetration into the market of financial services was $16 \%$, 
in 2017 - 33\%, in 2019 - 64\%. The largest market share belongs to FinTech companies in countries such as China and India - 87\%, Russia and South Africa - 82\%; Colombia, Peru, the Netherlands, Mexico, Ireland, Great Britain - more than $70 \%$. The lowest share is the USA - 46\%, Belgium and Luxembourg $-42 \%$, France $-35 \%$, and Japan $-34 \%$. Both banks and FinTechs provide services in the financial services market or its individual segments. Herewith, in 2019 FinTechs accounted for: money transfer and payments - 75\%, savings and investments $-48 \%$, budgeting and financial planning $-34 \%$, borrowing $-29 \%$, insurance $-27 \%$ [Global Fintech Adoption Index 2019].

In the formation of their own development strategy, modern banks can choose between two vectors: the first one is symbiosis with fintech companies (technology outsourcing), the second one is digital transformation which will turn the bank into fintech.

Digital transformation has become a defining trend for all participants in the banking market. Banking innovations increase the convenience and speed of obtaining banking services, which is especially important in the context of quarantine restrictions (Alghamdi et al 2018).

FinTech is a concept that emerged as a result of the interpenetration of finance and digital technologies and led to the transformation of business models of financial institutions. Currently, the market distribution of Fintech companies is as follows: $19 \%$ - the sphere of payments; $18 \%$ technology (infrastructure), 13\% - analytical systems, $11 \%$ - mobile wallets, $8 \%$ - lending, $8 \%$ blockchain (cryptocurrency). Digital transformations of banks take place gradually - from the simplest digital tools of interaction with the client to more complex ones (Fig. 1).

Figure 1. Stages of digitalization of banks

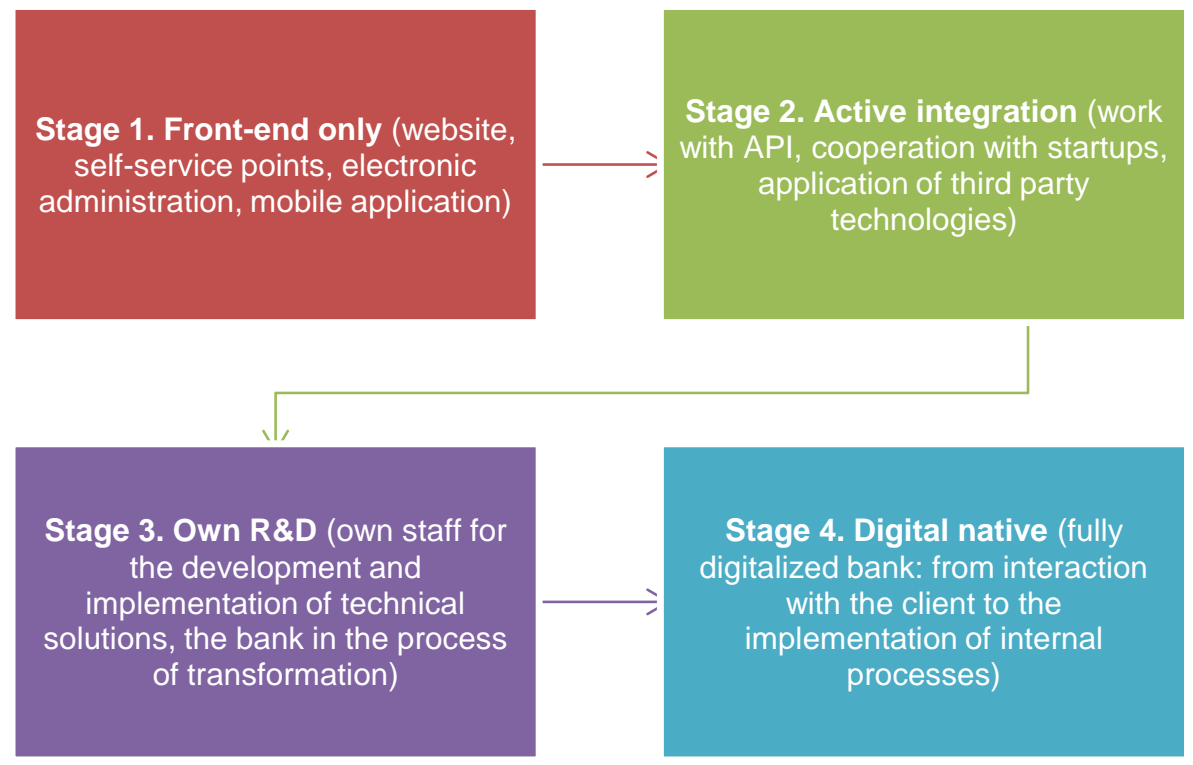

The processes of digital transformations and the implementation of banking innovations into the activity is influenced by several factors: the bank's readiness to digitize banking processes, adaptation of business models to the introduction of IT technologies; the presence of an extensive customer base focused on the consumption of complex banking services; availability of significant investments in the development of technological solutions (digital customer service channels, the formation of large databases and electronic cash flow accounting systems for customer transactions).

Based on the fact that credit operations account for the largest share in the structure of bank assets (about $70 \%$ ), banks have always competed in the credit services market, trying to attract more customers. The tools of competition in the credit market include both price tools (interest rate, commission), and non-price tools (requirements for the type and cost of collateral for the loan, quality of service, a package of documents to be provided by a potential borrower to obtain a loan, term credit, etc.). Cooperation with FinTech companies in the field of bank lending allows to increase the attractiveness of credit products for the client. The main purpose of such cooperation is to maximize 
customer satisfaction by increasing the speed and facilitating the provision of a wide range of financial services in one place. The undisputed leader in the market of credit services, in particular in the field of lending to individuals is JSC CB "Privatbank", which provides its customers with such digital services as "Privat24" mobile application, "Skarbnychka", "Privat24 Business", "My deposits", "PrivatBudget", "Bonus plus", "PrivatAgent", "Financial controller", "Credit history", "Discount club", "Payment in installments" service, SMS-banking, etc. One of the main competitors of JSCB "Privatbank" is the project of Fintech Band and Universal Bank called Monobank, which has become one of the most recognizable FinTech brands in Ukraine.

Taking into account the negative effects of the pandemic on the global economy and the speed of response of the banking sector to the challenges and threats of the environment, the forecast for net interest income of Ukrainian banks during 2018 - early 2021, which is formed as the difference between interest income and interest expense, has been made.

Given the negative effects of the pandemic on the global economy and the speed of response of the banking sector to the challenges and threats of the environment, the forecast for net interest income of Ukrainian banks during 2018 - early 2021, which is formed as the difference between interest income and interest expense.

Figure 7. The dynamics of values of net interest income of Ukrainian banks for January 2018 — March 2021

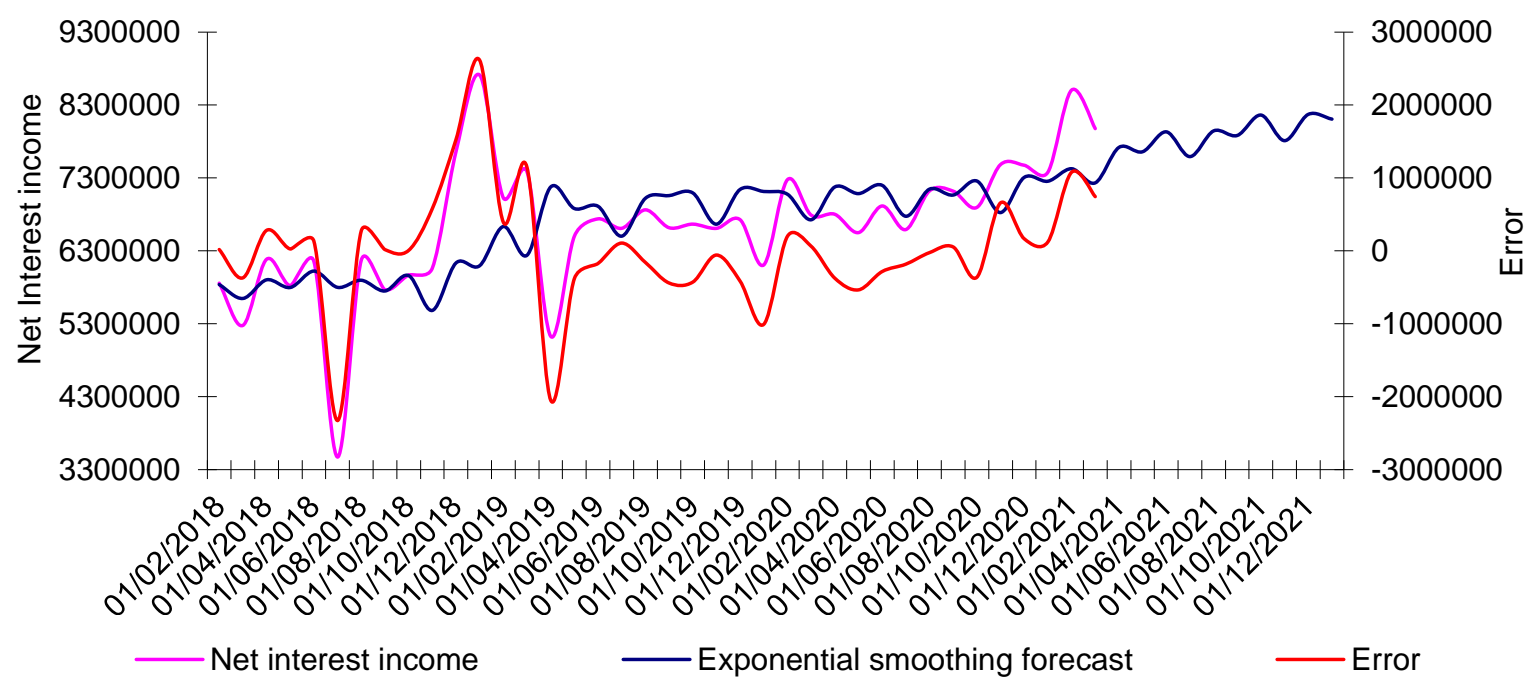

The use of a forecast model based on the principle of exponential smoothing, using a multiplicative trend and seasonal time interval (lag) 4, (the time lag was chosen according to the number of quarterly reporting periods), allowed to make an optimistic forecast of the value of net interest income in 2021 (Table 1). This indicates that there is sufficient capacity of domestic banks to meet the challenges posed by the pandemic.

Modern banks face the problem of choosing between three options for the implementation of digital banking technologies: to develop a digital product independently, turn to FinTech companies, or use existing ones on the market (for example, developed by foreign banks). Based on the fact that banking innovations require significant financial investments, most banks do not develop their own innovative products, but use existing ones.

Digitalization of the banking business, including one that is made through cooperation with FinTech startups, covers all aspects of the bank's activities, including internal and external innovations (Fig. 2). 

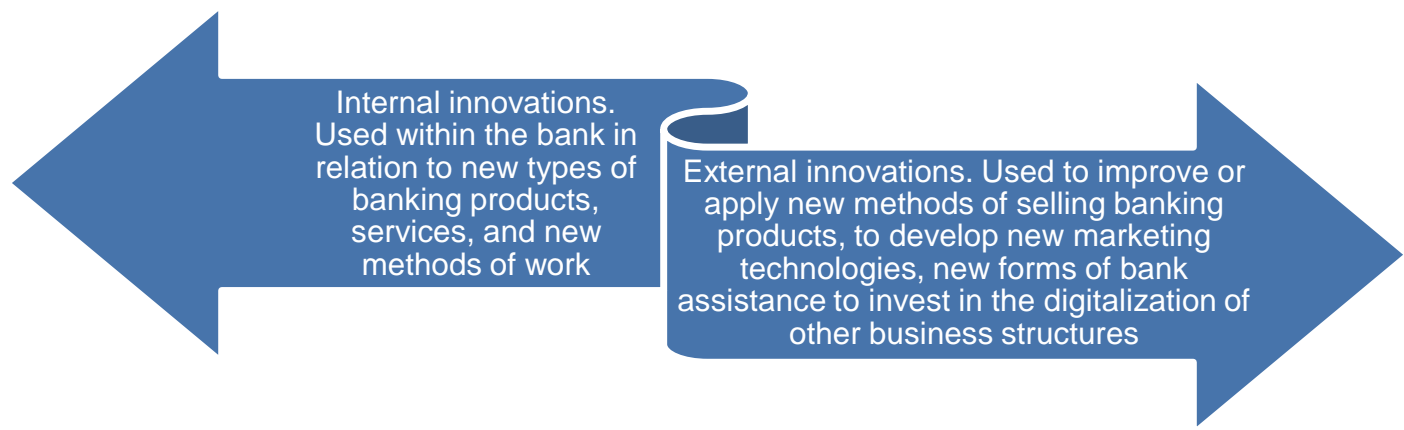

Figure 2. Internal and external innovations used in the process of digitalization of the bank

The strategic goals of the bank and the stages of its life cycle allow to choose the appropriate digitization policy (Fig. 3).

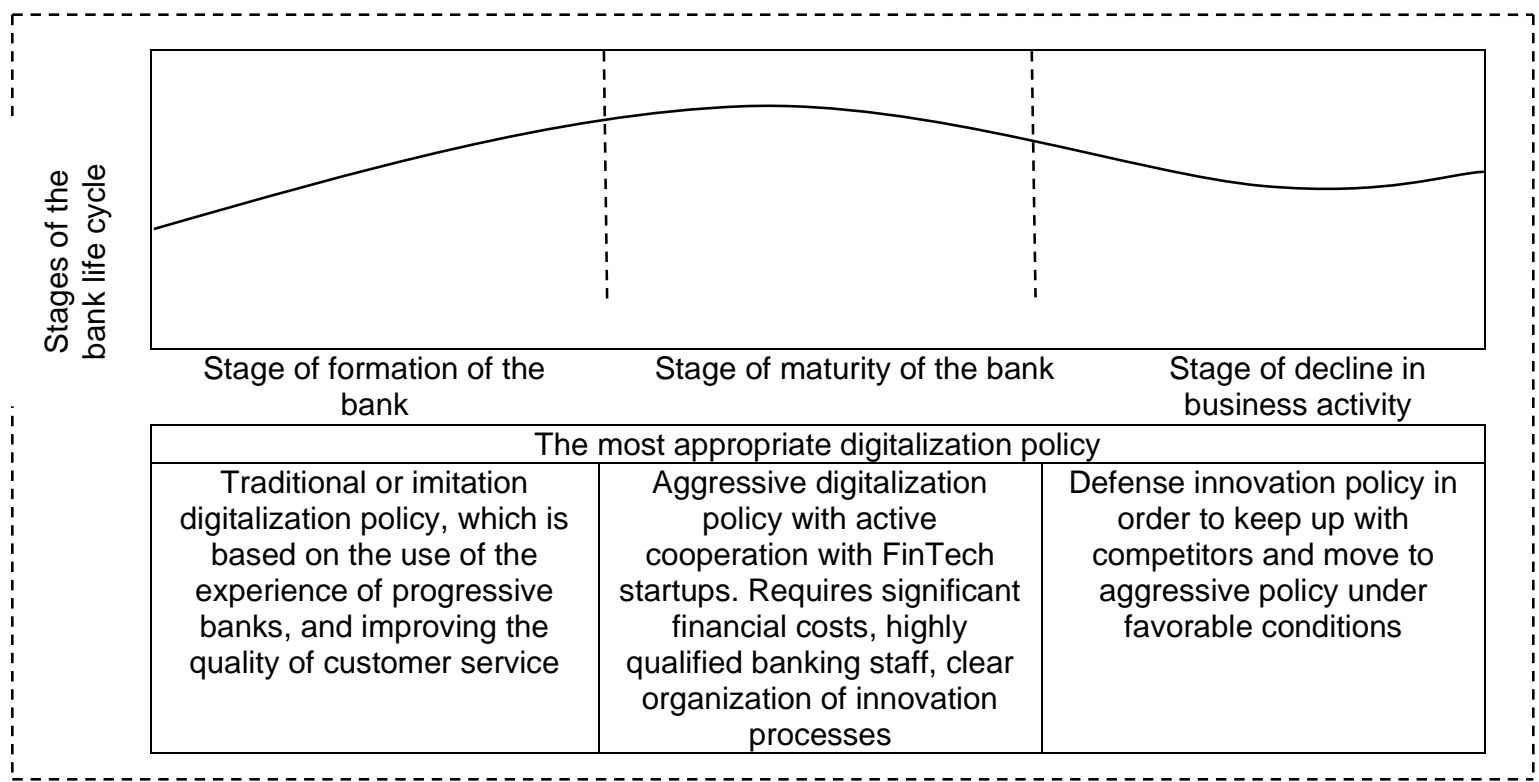

Figure 3. The most appropriate digitization policy depends on the stages of bank life cycle

Over the past few years, traditional financial institutions and non-traditional FinTech companies have begun to realize that collaboration can be the best way to increase the competitiveness and profitability of a business in the long run. The rationale for such cooperation is the ability to combine the strengths of both banks and FinTech companies (Fig.4). For most FinTech organizations, the main benefits are: innovative thinking, agility (speed of adjustment), consumer-oriented perspective, and infrastructure built for digital technologies. These are advantages that most traditional banks do not have.

Demand for products and services from FinTech companies and large technology companies is expected to increase as more consumers become acquainted with the new digital offerings. This is especially true for young consumers who have grown up with digital devices.

Unlike banks, FinTech companies operate in conditions of insufficient access to the customer base, financial experience, consumer confidence, reliable global infrastructure and regulatory framework. Fintech companies, working separately, on the one hand, pose a threat to banking competitiveness, as they provide new high-quality products based on digital technologies, and on the other hand, create opportunities to establish partnerships with banks.

Banks are looking for ways to benefit from FinTech. The analysis of data from 45 large banks over the past three years shows that institutions around the world remain mainly focused on the use of FinTech in payments and credit services. 


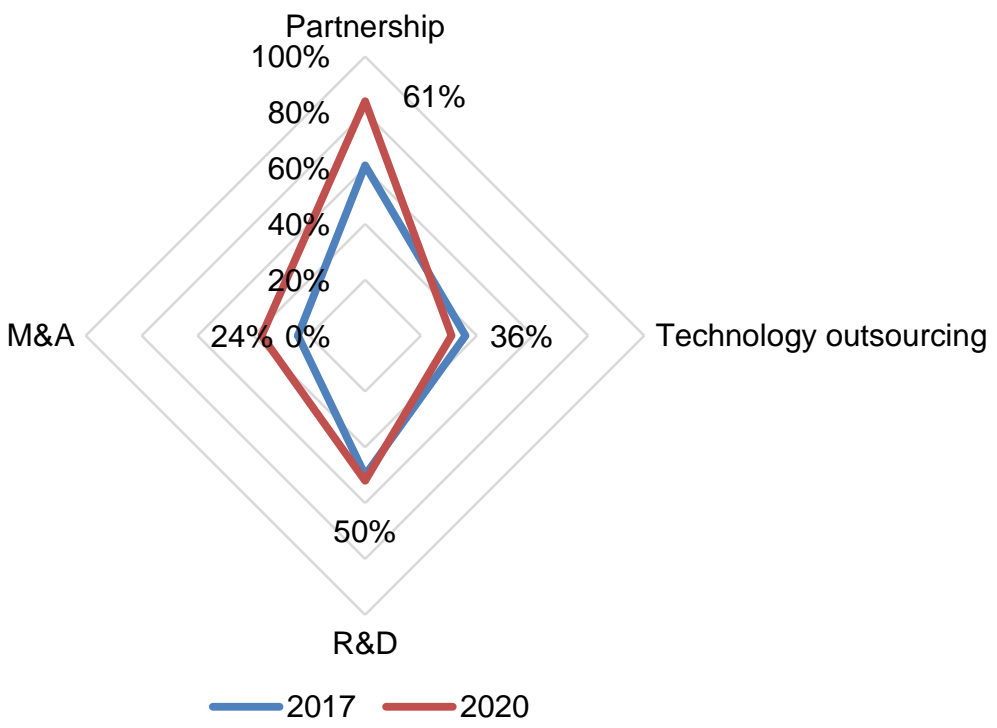

Figure 4. The keys are directly related to the interaction of traditional financial intermediaries with FinTech companies in 2017 and 2020. (\% of respondents) [KPMG]

The digital economy is changing the usual models of industry markets, increasing the competitiveness of market participants. Possession of digital assets gives business structures an additional competitive advantage, and the level of competitiveness of companies will be determined by the level of their digitalization.

The introduction of digital technologies pulls up increased competition, creating threats for existing leaders arising from new waves of innovation.

This is due to the fact that in the pre-digital era, economies of scale were achieved through an extensive network of bank branches and ATM machines. Significant scale required considerable time and resources. Digitalization allows to avoid such costs and scale in the short term due to IT platforms. Digital platforms provide access to the Internet for millions of users, which allows to collect, summarize, and analyze data about their priorities, consumer preferences. The introduction of digital technologies allows to reduce costs in the process of settlements and review own costs in the formation of the family budget, allows to optimally select banking products, get the necessary advice on the bank's website, provides transparency and more.

The following factors hinder the processes of intensification of interaction between banks and FinTech companies in Ukraine:

insignificant integration of innovative activities of domestic banks into the international financial space, which does not allow to turn venture projects into global businesses;

lack of developed infrastructure to support innovation and technology banks;

macroeconomic instability and insignificant share of investment-attractive innovationtechnological projects in the banking services market;

lack of state guarantees and legal mechanisms to protect intellectual property rights.

In modern conditions, the creation of FinTech companies requires significant financial investment (Fig. 4), due to the high cost of innovative developments in the financial sector, able to meet customer needs and requirements in the long run (as far as possible, in a short life cycle of banking innovation). 


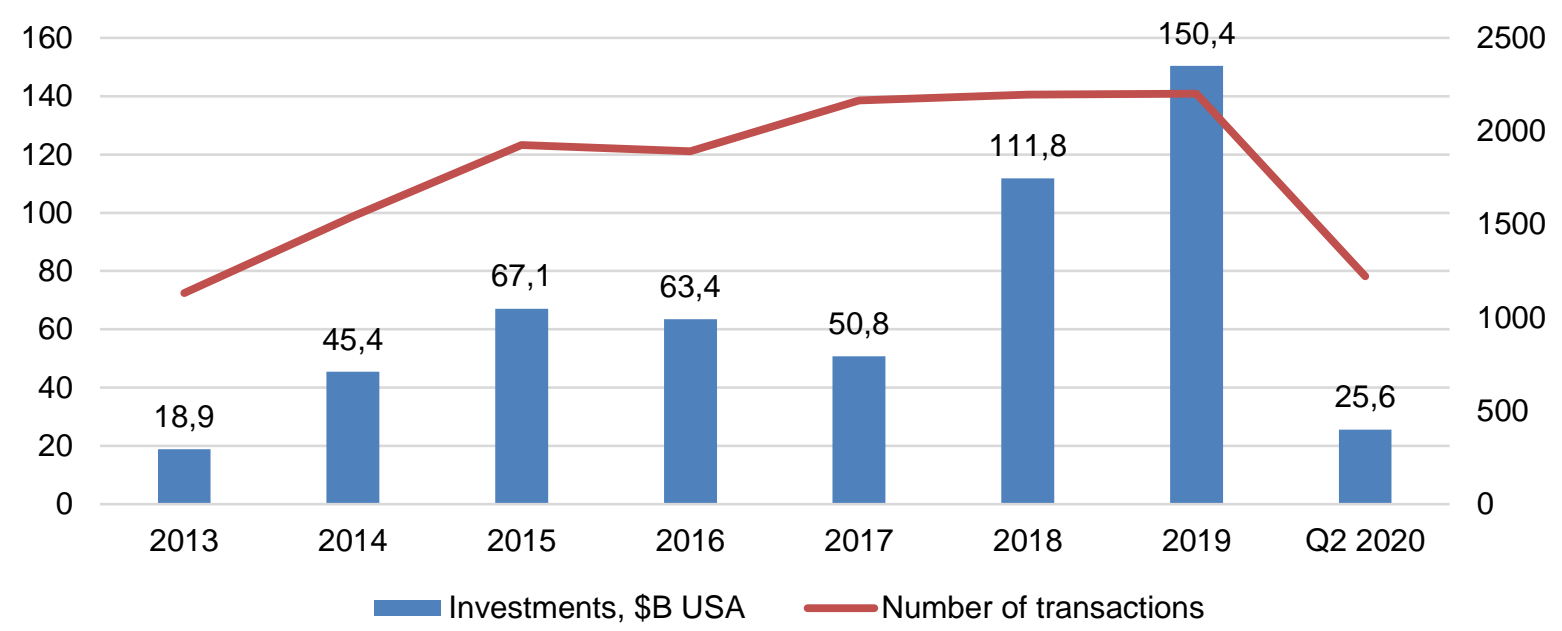

Figure 5. Global investments in FinTech companies in 2013-I half of 2020 [Pulse of Fintech H1'20]

An indicator of a country's success in implementing the norms and measures of the Digital Agenda for the EU and the Digital Single Market is the Digital Economy and Society Index (DESI), which is determined for each EU country annually (Fig. 4). It is used to assess the level of technological development, digital competitiveness, as well as the degree of introduction of innovative technologies in the European Union by the following components: Connectivity (25\%), Human Capital (25\%), Use of Internet (15\%), Integration of Digital Technology (20\%), Digital Public Services (15\%).

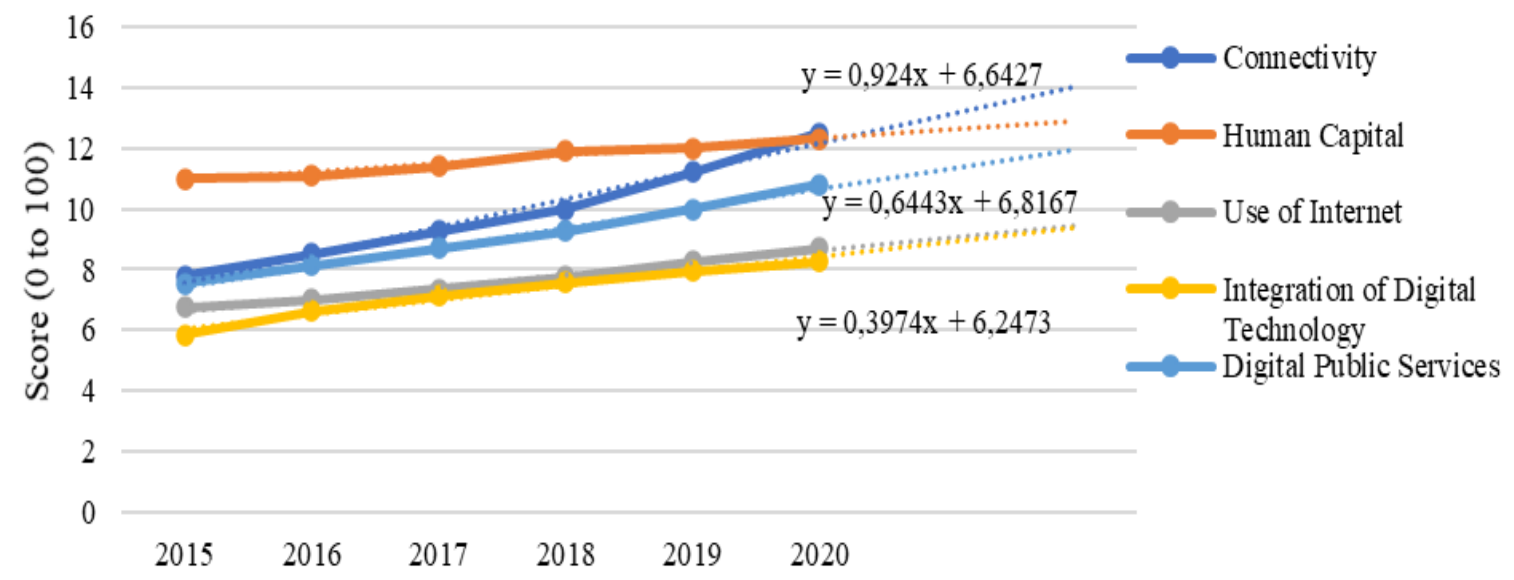

Figure 6. Digital Economy and Society Index, by Main Dimensions of the DESI, 2015-2020

The dynamics of the DESI index in the EU countries according to the above indicators is shown in Table 1.

In the context of digital transformations, the bank's competitiveness is determined not only by the level of implemented digital technologies and innovative services, but also by the availability of resources to help customers make informed decisions about investing in digital technologies, find opportunities to achieve the goal, optimize risks and increase profitability. Introduction of digital technologies and FinTech innovations allows to open a general portal for servicing and provide fast access to financial information for customers, consolidate customers' accounts on various operations, provide a complex of products and services, provide efficiency of carrying out and standardization of operations. Such technologies include: cloud technologies, blockchain, artificial intelligence (Al), big data, biometrics, application programming interfaces (API), etc. 
Viktoriia Vovk, Alina Denysova, Kateryna Rudoi, Tetiana Kyrychenko

Table 1. Comparative dynamics of the DESI index in the EU in 2020

\begin{tabular}{|c|c|c|c|c|c|c|}
\hline EU & Connectivity & Human Capital & $\begin{array}{l}\text { Use of } \\
\text { Internet }\end{array}$ & $\begin{array}{l}\text { Integration of } \\
\text { Digital } \\
\text { Technology }\end{array}$ & $\begin{array}{l}\text { Digital Public } \\
\text { Services }\end{array}$ & DESI \\
\hline Finland & 14,8 & 19,6 & 11,5 & 13,4 & 13 & 72,3 \\
\hline Sweden & 16,1 & 17,9 & 11,4 & 12,4 & 11,9 & 69,7 \\
\hline Denmark & 16,5 & 15,3 & 11,3 & 13 & 13,1 & 69,2 \\
\hline Netherlands & 15,1 & 16 & 11,3 & 13,1 & 12,1 & 67,6 \\
\hline Malta & 14,7 & 15,4 & 9,89 & 11 & 11,7 & 62,69 \\
\hline Ireland & 11,4 & 14,1 & 9,31 & 14,9 & 12,1 & 61,81 \\
\hline Estonia & 13 & 16,7 & 9,81 & 8,23 & 13,4 & 61,14 \\
\hline UK & 12,2 & 15,8 & 11 & 10,8 & 10,6 & 60,4 \\
\hline Belgium & 13 & 12,6 & 9,17 & 13,2 & 10,8 & 58,77 \\
\hline Luxembourg & 15,8 & 14,6 & 8,83 & 7,64 & 11,1 & 57,97 \\
\hline Spain & 15,2 & 11,9 & 9,12 & 8,24 & 13,1 & 57,56 \\
\hline Germany & 14,8 & 14,1 & 9,23 & 7,91 & 9,96 & 56 \\
\hline Austria & 11,8 & 14,2 & 8,1 & 8,12 & 12,1 & 54,32 \\
\hline Lithuania & 12,2 & 11 & 8,6 & 9,89 & 12,2 & 53,89 \\
\hline EU & 12,5 & 12,3 & 8,7 & 8,27 & 10,8 & 52,57 \\
\hline France & 12,5 & 11,9 & 7,96 & 8,41 & 11,5 & 52,27 \\
\hline Slovenia & 12,6 & 12,1 & 7,76 & 8,19 & 10,6 & 51,25 \\
\hline Czechia & 11,2 & 12,2 & 8,12 & 9,92 & 9,36 & 50,8 \\
\hline Latvia & 15,4 & 8,76 & 8,1 & 5,66 & 12,8 & 50,72 \\
\hline Portugal & 13,5 & 9,44 & 7,21 & 8,17 & 11,3 & 49,62 \\
\hline Croatia & 10,3 & 12,3 & 8,32 & 8,29 & 8,36 & 47,57 \\
\hline Hungary & 14,9 & 10,5 & 8,38 & 5,06 & 8,67 & 47,51 \\
\hline Slovakia & 11,9 & 10,5 & 8 & 6,51 & 8,34 & 45,25 \\
\hline Poland & 12,8 & 9,32 & 7,45 & 5,25 & 10,1 & 44,92 \\
\hline Cyprus & 9,61 & 8,95 & 8,17 & 6,9 & 10,3 & 43,93 \\
\hline Italy & 12,5 & 8,11 & 6,67 & 6,25 & 10,1 & 43,63 \\
\hline Romania & 14 & 8,29 & 5,38 & 4,99 & 7,26 & 39,92 \\
\hline Greece & 8,34 & 8,7 & 6,91 & 5,64 & 7,73 & 37,32 \\
\hline Bulgaria & 9,62 & 8,48 & 5,5 & 3,57 & 9,26 & 36,43 \\
\hline
\end{tabular}

\section{Conclusions}

The digitalization of the banking business and the transformation of business models of customer service allows us to take those banks that quickly adapt to digital transformation to a new level. The symbiosis of banks and FinTech companies may become a new trend for the banking services market in general and the consumer lending market in particular. This is due to the fact that the introduction of banking innovations can increase the attractiveness of credit services for customers. Under these circumstances, the competitiveness and profitability of the banking business is determined by the capabilities and willingness of banks to implement innovations based on the use of digital technologies. The synergistic effect of the symbiosis of banks and FinTech companies is to increase competitiveness and financial stability in the conditions of uncertainty of the pandemic consequences in the long run. Among the main factors that inhibit the processes of strengthening the interaction between banks and FinTech companies in Ukraine are: high cost and short life of banking innovations; low readiness of the bank for the transformation of banking business processes and business areas; insufficient level of development of the banking services market in comparison with the banking services markets of the leading countries, lack of legal norms regulating the issues of such interaction.

\section{Acknowledgements}

The publication contains the results of studies conducted on the initiative research work "Strategy of structural reorientation of Ukraine's economy in pandemic". 


\section{References}

1. Alghamdi, A., \& Akbar, M. K. (2018). Implementation of an Implicit Solver in ADCIRC Storm Surge Model. Journal of Marine Science and Engineering, 6(2), 62.

2. Babenko, V., Perevozova, I., Mandych, O., Kvyatko, T., Maliy, O., Mykolenko, I., (2019). World informatization in conditions of international globalization: Factors of influence. Global Journal of Environmental Science and Management, 5 (Special issue), pp. 172-179. http://dx.doi.org/10.22034/gjesm.2019.05.SI.19

3. Bilovodska, O., Gaidabrus, N., Sager, L. (2014). Logistic Service in the Innovative Production Distribution Channels as its Optimal Structure Factor. Actual Problems of Economics, 11: 147-153.

4. Bilovodska, O.; Kholostenko, A.; Mandrychenko, Zh.; Volokitenko, O. (2021). Innovation management of enterprises: legal provision and analytical tools for evaluating business strategies. Journal of Optimization in Industrial Engineering, 14 (1): 89-96. URL: http://www.qjie.ir/article_677820_05763483c76a89d1fb9b4b6f865089ae.pdf.

5. Bilovodska, O.; Melnyk, Yu.; Alenin, Yu.; Arkusha, L. (2020). Implementation of Marketing and Legal Tools in the Process of Commercialization for Innovative Products in Strategic Management and Entrepreneurship. International Journal for Quality Research, 14 (4): 1261-1278. URL: http://www.ijqr.net/paper.php?id=880.

6. Bilovodska, O.; Starostina, A.; Vovk, V.; Moroz, O.; Moroz, M. (2020). Environmental packaging in trade logistics and innovative entrepreneurship based on Internet marketing online research and communications. Estudios de Economia Aplicada: 38-3 (1). DOI: 10.25115/eea.v38i3\%20(1).3993.

7. Chmutova I., Vovk V., Bezrodna O. (2017). Analytical tools to implement integrated bank financial management technologies. Economic Annals-XXI, 163(1-2(1)), 95-99.

8. Compare the evolution of DESI components. URL: https://digital-agenda-data.eu/charts/desi-seethe-evolution-of-an-indicator-and-comparebreakdowns\#chart=\{\%22indicator\%22:\%22desi\%22,\%22breakdowngroup\%22:\%22desi\%22,\%22unit-measure\%22:\%22egov_score\%22,\%22ref-area\%22:\%22EU\%22\}

9. Directive (EU) 2015/2366 of the European Parliament and of the Council of 25 November 2015 on payment services in the internal market. URL: https://eur-lex.europa.eu/legalcontent/EN/TXT/PDF/?uri=CELEX:32015L2366\&from=EN.

10.Directive 2007/64/EC of the European Parliament and of the Council of 13 November 2007 on payment services in the internal market. URL: https://eur-lex.europa.eu/LexUriServ/ LexUriServ.do?uri=OJ:L:2007:319:0001:0036:en:PDF.

11.Dubyna, M., Zhavoronok, A., Kudlaieva, N., Lopashchuk, I. (2021). Transformation of household credit behavior in the conditions of digitalization of the financial services market. Journal of Optimization in Industrial Engineering, 14(1), 97-102.

12.Gai, K., Qiu, M., \& Sun, X. (2018). A survey on FinTech. Journal of Network and Computer Applications, 103, 262-273. DOI: 10.1016/j.jnca.2017.10.011.

13.Gryshchenko, I., Chubukova, O., Bilovodska, O., Gryshchenko, O., Melnyk, Yu. (2020). Marketingoriented Approach to Evaluating the Strategy of Distribution Management for Innovative Products in Logistics. WSEAS Transactions on Environment and Development, Vol. 16. Art. \# 37: 371-383. DOI: $10.37394 / 232015.2020 .16 .37$.

14.Hrabovskyi, Y., Babenko, V., Al'boschiy, O., Gerasimenko, V. (2020). Development of a Technology for Automation of Work with Sources of Information on the Internet. WSEAS Transactions on Business and Economics, 17(25), 231-240. https://doi.org/10.37394/23207.2020.17.25

15.KPNG (2020). Pulse of Fintech H1'20, 77 p. URL: https://assets.kpmg/content/dam/kpmg/ xx/pdf/2020/09/pulse-of-fintech-h1-2020.pdf.

16.Malyarets, L.M., Babenko, V.O., Nazarenko, O.V., Ryzhikova, N.I. (2019). The Modeling of Multicriteria Assessment Activity in Enterprise Management, Int. J Sup. Chain. Mgt, vol. 8, no. 4, pp. 997- 
1004. http://ojs.excelingtech.co.uk/index.php/IJSCM/article/view/3342

17.Sievidova, I., Oliynyk, T., Mandych, O., ...Vynohradenko, S., Plyhun, S. (2019). Optimizing the strategy of activities using numerical methods for determining equilibrium, Eastern-European Journal of Enterprise Technologies, 6(4-102), p. 47-56.

18.Martini, L., Stegemann, U., Windhagen, E., Hueser, M., Schneider, S., Poppensieker, T., et al. (2009). Bad banks: Finding the right exit from the financial crisis. McKinsey Working Paper on Risk.

19.National Bank of Ukraine (2020). Ukrainian banks' financials as of January 1, 2013-2019. URL: https://bank.gov.ua/control/en/publish/article?art_id=34705283\&cat_id= 34798612.

20.Naveed, Q. N., Qureshi, M. R. N. M., Shaikh, A., Alsayed, A. O., Sanober, S., \& Mohiuddin, K. (2019). Evaluating and ranking cloud-based e-learning critical success factors (CSFs) using combinatorial approach. IEEE Access, 7, 157145-157157.

21.Pantielieieva, N., Krynytsia, S., Zhezherun, Y., Rebryk, M., POTAPENKO, L. (2018). Digitalization of the Economy of Ukraine: Strategic Challenges and Implementation Technologies. IEEE Xplore. DOI: 10.1109/DESSERT.2018.8409186.

22.Podgorna, I., Babenko, V., Honcharenko, N., Sáez-Fernández, F. J., Fernández, J. A. S., Yakubovskiy, S. (2020). Modelling and Analysis of Socio-Economic Development of the European Union Countries through DP2 Method. WSEAS Transactions on Business and Economics, Volume 17, Art. \#44, pp. 454-466. https://doi.org/10.37394/23207.2020.17.44

23.Shkarlet, S., Dubyna, M., Shtyrkhun, K., Verbivska, L. (2020). Transformation of the paradigm of the economic entities development in digital economy. WSEAS Transactions on Environment and Development, 16, 413-422.

24.Shkarlet, S., Dubyna, M., Vovk, V., Noga, M. (2019). Financial service markets of Eastern Europe: A compositional model. Economic Annals-XXI, 176(3-4), 26-37.

25.Strategy for the development of the financial sector of Ukraine until 2025 (updated in March 2021). URL: https://bank.gov.ua/ua/news/all/strategiya-rozvitku-finansovogo-sektoru-ukrayini-do-2025roku-7686.

26. Thakor, A. V. (2020). Fintech and banking: What do we know? Journal of Financial Intermediation, 41, 100833. DOI: 10.1016/j.jfi.2019.100833.

27.The Law Of Ukraine "On Consumer Lending" of 15.11.2016 № 1734-VIII. URL: https://zakon.rada.gov.ua/laws/show/1734-19\#Text.

28.The Law Of Ukraine "On Currency And Currency Transactions" of 21.06.2018 №2473-VIII. URL: https://zakon.rada.gov.ua/laws/show/2473-19\#Text.

29.The Law Of Ukraine "On Electronic Trust Services" of 05.10.2017 №2155-VIII. URL: https://zakon.rada.gov.ua/laws/show/2155-19\#Text.

30.The Law Of Ukraine "On Financial Services And State Regulation Of Financial Services Markets" of 12.07.2001 №2664-III. URL: https://zakon.rada.gov. ua/laws/card/2664-14.

31.The Law Of Ukraine "On Payment Systems And Funds Transfer In Ukraine" of 05.04.2001 №2346III. URL: https://zakon.rada.gov.ua/laws/show/2346-14\#Text.

32.Vovk, V, Zhezherun, Y, Bilovodska, O, Babenko, V, Biriukova, A. (2020). Financial Monitoring in the Bank as a Market Instrument in the Conditions of Innovative Development and Digitalization of Economy: Management and Legal Aspects of the Risk-Based Approach. IJIEPR. 31 (4), 559-570. https://doi.org/10.22068/ijiepr.31.4.559

33.Vovk, V., Zhezherun, Y., Gudz, L., Perederii, O. (2021). Innovative instruments and legal mechanisms of bank capitalization: national features and world trends. Journal of Optimization in Industrial Engineering, 14(1), 191-198.

34.Yaseen, S., Abbas, S. M. A., Anjum, A., Saba, T., Khan, A., Malik, S. U. R., ... \& Bashir, A. K. (2018). Improved generalization for secure data publishing. IEEE Access, 6, 27156-27165. 
Management and Legal Aspects of the Symbiosis of Banking Institutions and Fintech Companies in the Credit Services Market in the Context of Digitization

35. Global Fintech Adoption Index 2019. URL: https://www.ey.com/en_gl/ey-global-fintech-adoptionindex 